\title{
PEMILIHAN TEKNOLOGI DAUR ULANG AIR LIMBAH DOMESTIK DI KANTOR BPPT
}

\author{
Satmoko Yudo dan Taty Hernaningsih
}

Pusat Teknologi Lingkungan, BPPT

JIn. MH. Thamrin No.8 Jakarta Pusat. Gedung II Lt.20

\begin{abstract}
The increasing variety of industrial activities in Indonesia resulted in ground water reserves in some areas experiencing drought. Exploitation of ground water by industry and the community in some big cities like Jakarta, resulting in the decrease of ground water and ground water quality reduced caused sea water instrusion. While the potential of wastewater produced by industrial and household waste high today. Based on the matters mentioned above and see the use of ground water that will be even greater in the future, then one of alternative that a lot of attention in many countries around the world are using wastewater reuse, particularly urban domestic wastewater (municipal wastewater) as a source of raw water for water supply. BPPT as a government office has made use of wastewater reuse technology, however, when the performance of the appliance is not working properly for it is necessary for re-evaluation and selection of wastewater reuse technology for better and sustainable.
\end{abstract}

Keywords : Wastewater Reuse Technology, Domestic Wastewater, Water Consumption Survey

\section{PENDAHULUAN}

Meningkatnya kegiatan industri dan perkantoran di Jakarta menyebabkan pemakaian air tanah yang terus menerus serta jumlahnya yang semakin besar dapat mengakibatkan berkurangnya cadangan air tanah, menurunnya muka air tanah dan berkurangnya kualitas air tanah karena instrusi air laut. Ditambah meningkatnya jumlah penduduk Jakarta, yang diperkirakan akan menimbulkan permasalahan dalam penyediaan sarana kebutuhan air bersih, sebab saat ini baru $60 \%$ dari total penduduk yang dapat terlayani oleh sistem penyediaan air bersih dari PAM DKI Jakarta (1). Penduduk yang belum mendapat pelayanan air bersih masih harus mengandalkan penyediaan air bersih dari sumber air tanah.

Penyebab menurunnya kualitas air tanah selain disebabkan oleh intrusi air laut, adalah akibat pencemaran limbah cair. Sumber dari pencemaran limbah cair tesebut tidak hanya berasal dari buangan industri yang membuang air limbahnya tanpa pengolahan lebih dahulu, tetapi juga yang tidak kalah memegang andil adalah limbah domestik yang jumlahnya makin hari semakin besar sesuai dengan perkembangan penduduk maupun perkembangan wilayah kota. Hasil pemeriksaan Suku Dinas Kesehatan DKI Jakarta terhadap limbah domestik, hanya $74 \%$ yang memenuhi persyaratan fisik kimia. Sedangkan yang memenuhi persyaratan bakteriologis sekitar $43 \%$ (2). Data tersebut menunjukkan bahwa sebagian besar air limbah di Jakarta masih mencemari lingkungan sekitarnya.

Berdasarkan hal-hal tersebut di atas serta melihat penggunaan air tanah yang akan semakin besar di masa mendatang, maka perlu dipikirkan bersama pemecahan yang terpadu untuk menangani masalah kebutuhan air bagi penduduk DKI Jakarta. Salah satu alternatif yang banyak mendapat perhatian di banyak negara di dunia adalah dengan melakukan daur ulang air limbah khususnya air limbah domestik perkotaan (municipal waste).

Ini merupakan langkah yang sangat tepat, terutama dilakukan untuk unit-unit usaha yang membutuhkan air bersih dalam jumlah yang besar. Ada beberapa keuntungan yang dapat diperoleh dari daur ulang air limbah, antara lain (3):

1. Mengurangi ketergantungan pada air PAM dan air tanah,

2. Mengurangi pemakaian air PAM dan air tanah, sekaligus menghemat biaya untuk pengadaan air bersih,

3. Mengurangi jumlah air limbah yang dibuang ke badan penerima.

4. Menghemat penggunaan sumber daya alam dan ikut melestarikan lingkungan,

5. Dengan teknologi yang semakin maju, dapat melakukan proses daur ulang yang lebih murah sehingga dapat menghemat pengeluaran. 


\section{TUJUAN DAN SASARAN}

Tujuan dari kegiatan yang akan dilakukan adalah melakukan perencanaan disain teknologi daur ulang air limbah perkantoran dengan sasaran mendapatkan teknologi daur ulang air limbah yang tepat, dan dapat meningkatkan efisiensi penggunaan air. Obyek kegiatan ini adalah kantor BPPT yang berlokasi di Jl. M.H. Thamrin No. 8 Jakarta Pusat.

\section{RUANG LINGKUP} berikut

Lingkup dari kegiatan ini adalah sebagai

1. Survei lapangan kantor BPPT Jakarta,

2. Pengolahan dan analisis data hasil survei.

3. Perancangan teknologi daur ulang air limbah domestik kantor BPPT Jakarta.

\section{METODOLOGI}

Metodologi yang digunakan dalam kegiatan ini adalah :

\section{A. Metoda Analisis}

diambil adalah:

Dalam metoda ini langkah-langkah yang

- Survei dilakukan untuk mengetahui jumlah pegawai yang ada, pemakaian air dan kondisi unit daur ulang air limbah yang digunakan saat ini.

- Studi banding dilakukan untuk identifikasi teknologi daur ulang air limbah yang telah diterapkan saat ini.

- Menganalisis kondisi unit daur ulang untuk memperoleh gambaran sistem pengelolaan daur ulang air limbah saat ini.

\section{B. Metode Perancangan}

Dalam metode ini digunakan untuk mendapatkan disain teknologi daur ulang air limbah domestik. Perancangan diawali dengan melakukan identifikasi kondisi, kualitas dan jumlah air limbah domestik serta yang di daur ulang saat ini serta penggunaan hasil daur ulang air limbah.

\section{DAUR ULANG AIR LIMBAH}

Daur ulang air limbah adalah penggunaan kembali air limbah untuk tujuan seperti irigasi pertanian, irigasi landscape (taman, halaman sekolah/ perkantoran, lapangan Golf, jalan raya, jalur Hijau, makam, perumahan dll.), proses industri, bilas toilet (toilet flushing) dll.
Tujuan dari daur air limbah adalah untuk melakukan penghematan biaya pemakaian air bersih (PDAM / fres water). Saat ini daur ulang air limbah di beberapa daerah sudah lebih murah dibanding menggunakan air PDAM, sehingga sudah banyak perusahaan yang melakukan daur ulang limbah. Daur ulang dengan teknologi reverses osmosis dapat menghasilkan kualitas air yang sangat tinggi, sehingga dapat dimanfaatkan untuk berbagai keperluan seperti minum, proses produksi dll. Dengan semakin berkembangnya teknologi ini diharapkan sistem daur ulang ini akan semakin besar dalam berkontribusi untuk pemanfaatan sumber daya air yang lebih berkelanjutan ${ }^{(4)}$.

Salah satu contoh kota di dunia yang menggunakan sistem daur ulang air limbah adalah Tokyo. Dalam sebuah proyek daur air limbah di daerah Shinjuku di Tokyo, sebuah sistem distribusi ganda telah diadopsi dan air limbah dari unit pengolahan air limbah Kota Ochiai disaring (sand filter) kemudian diklorinasi untuk digunakan sebagai air pembilas toilet di 25 gedung bertingkat tinggi, seperti digambarkan dalam Gambar 1. Sistem daur ulang air limbah ini telah berhasil beroperasi sejak tahun $1984{ }^{(4)}$.

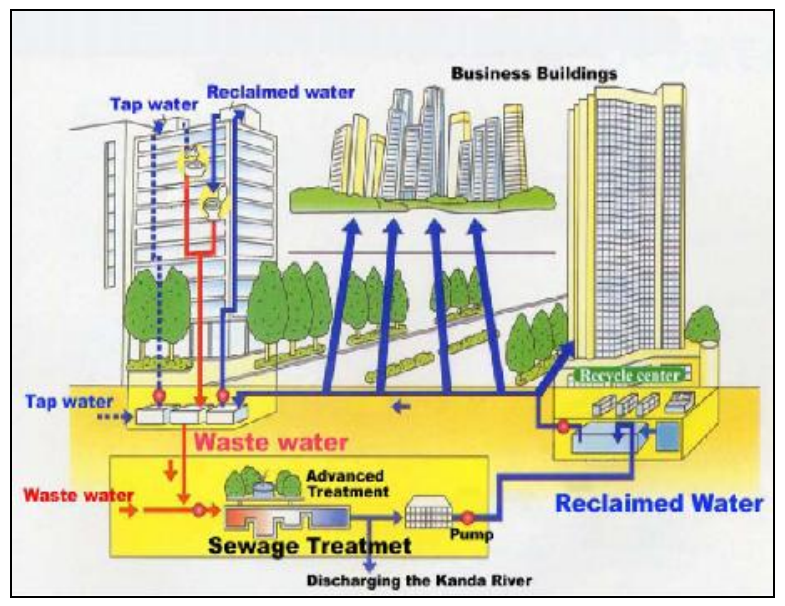

Gambar 1. Daur Ulang Air Limbah Di Tokyo

\section{HASIL KEGIATAN}

\subsection{Observasi dan Survei}

Langkah pertama adalah melakukan observasi dan survei yaitu:

a) Obyek penelitian (Kantor BPPT) meliputi luas area kantor dan jumlah pegawai BPPT.

b) Pemakaian air di kantor BPPT tiap bulan.

c) Kondisi Unit Alat Daur Ulang Air Limbah yang digunakan saat ini. 


\section{a. Luas area Kantor BPPT}

Luas area kantor BPPT adalah sekitar $17.119 \mathrm{~m}^{2}$. (Gambar 2.) Data luas area kantor BPPT digunakan untuk mengetahui seberapa luas cakupan luas tanaman yang akan disiram. Mengambil referensi Peraturan Menteri Dalam Negeri Nomor 1 Tahun 2007 Tentang Penataan Ruang Terbuka Hijau Kawasan Perkotaan (7) bahwa minimal $20 \%$ dari luas kawasan merupakan daerah hijau. Apabila 20\% dari luar kantor BPPT merupakan luas kawasan hijau, maka $3.424 \mathrm{~m}^{2}$ merupakan lahan tanaman atau pepohonan yang harus disiram. Apabila konsumsi tanaman 0,5 liter $/ \mathrm{m}^{2} /$ hari, maka kebutuhan air untuk siram tanaman adalah 1.712 liter/hari.

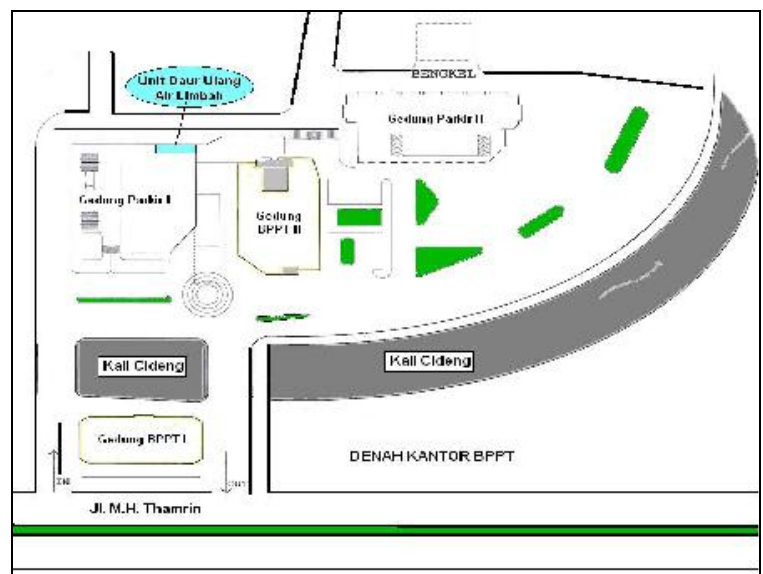

Gambar 2. Lay Out Area Kantor BPPT dan Lokasi Unit Daur Ulang Air Limbah yang Ada Saat Ini

Jumlah pegawai organik BPPT adalah 2.375 karyawan (6). Sedangkan total pegawai yang yang menempati kantor BPPT adalah 3.082 orang. Terdiri dari pegawai BPPT, RISTEK, DRN, Koperasi, Dharma Wanita, Satpam, Supir, Cleaning Service dan Perusahaan-perusahaan. (Gambar 3 \& 4).

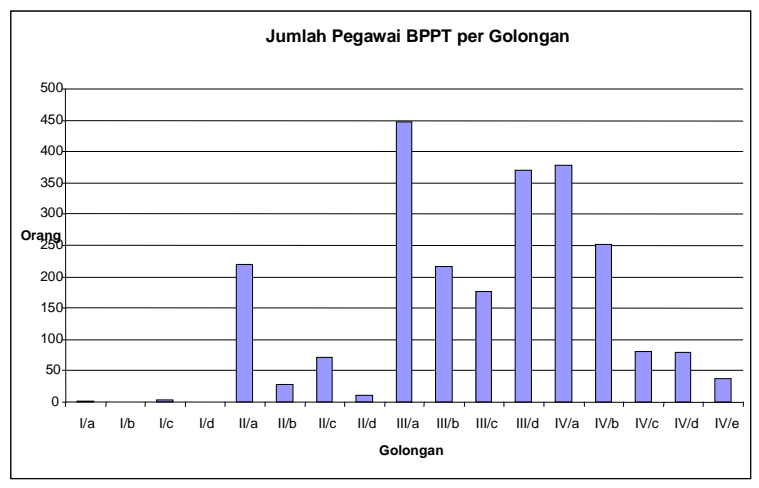

Gambar 3. Pegawai Organik BPPT Sesuai Golongan

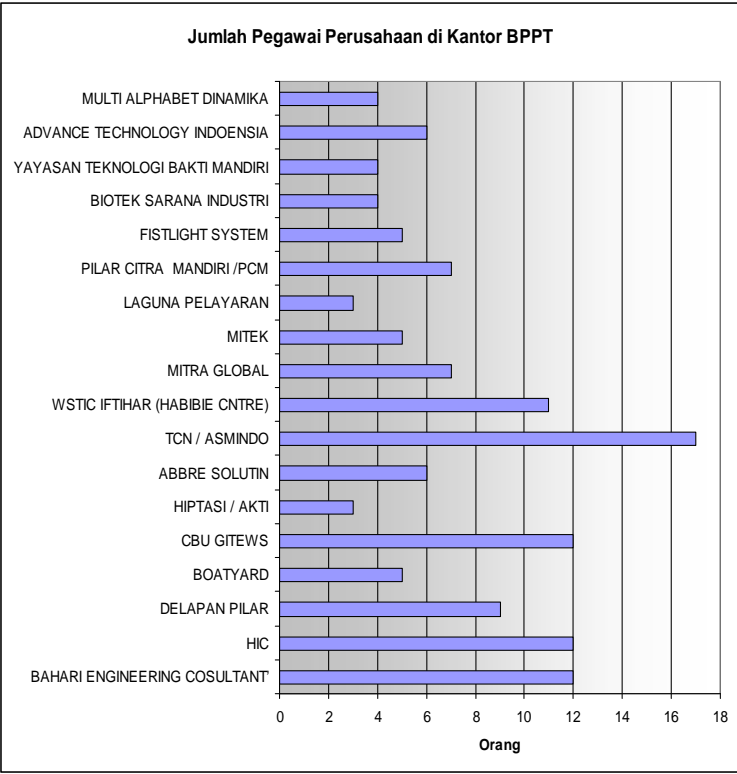

Gambar 4. Jumlah Pegawai Perusahaan Yang Berada Di Gedung BPPT

Apabila diasumsikan setiap hari terdapat pegawai dari luat kantor BPPT yang melakukan aktivitas makan di kantin termasuk para pedagangnya, maka diperkirakan terdapat sekitar 300 orang setiap harinya. Jadi total pegawai yang menempati kantor BPPT setiap hari yaitu 3.382 orang.

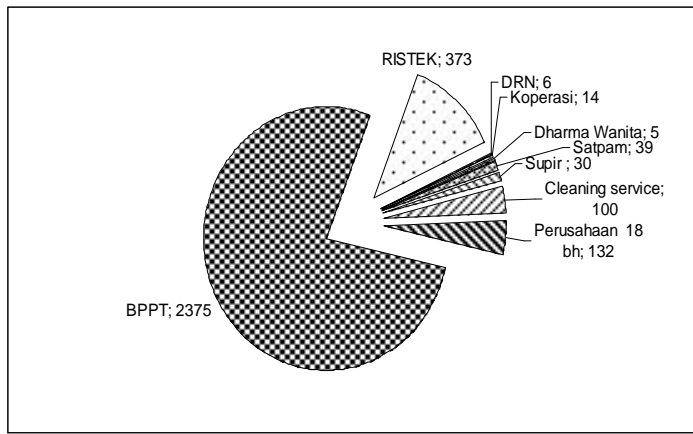

Gambar 5. Jumlah Pegawai Yang Ada di Kantor BPPT

\section{a. Pemakaian air di kantor BPPT tiap bulan.}

Untuk menghitung kapasitas unit daur ulang digunakan 2 (dua) pendekatan yaitu pertama pendekatan berdasarkan pemakaian air PAM di kantor BPPT setiap bulan dan kedua dengan pendekatan pemakaian air berdasarkan jumlah pegawai sesuai PerGub DKI Jakarta.

\section{a.1. Pemakaian air berdasarkan pemakaian air PAM setiap bulan}

Rata-rata pemakaian air PAM dari bulan Mei 2009 sampai Maret 2010 di BPPT adalah 6.972 
$\mathrm{m}^{3}$ perbulan, atau $234,2 \mathrm{~m}^{3}$ perhari. Terlihat bahwa pemakaian air rata2 perhari di kantor BPPT cukup besar dan tidak ada data rincian penggunaan air tersebut untuk apa saja. Apabila diasumsikan $80 \%$ dari pemakaian air tersebut akan menjadi air limbah, maka kapasitas minimal pengolah air limbah minimal adalah $80 \%$ x 234,2 $\mathrm{m}^{3}=185,9 \mathrm{~m}^{3}$ perhari.

Kapasitas pengolah air limbah yang diperkirakan aman menampung adalah $250 \mathrm{~m}^{3}$ perhari dengan asumsi apabila terjadi penambahan sampai $30 \%$ perubahan jumlah air limbah, maka unit pengolah air limbah masih aman. Apabila minimal 30\% air limbah tersebut di daur ulang, maka air hasil daur ulang sebesar $30 \% \times 185,9 \mathrm{~m}^{3}=55,8 \mathrm{~m}^{3}$ perhari.

\section{a.2. Pemakaian air berdasarkan jumlah pegawai}

Berdasarkan PerGub DKI Jakarta No. 122 tahun 2005, pemakaian air untuk di perkantoran 50 liter/pegawai/hari (6), maka kebutuhan air bersih untuk gedung/kantor BPPT sebesar 3.382 orang $\times 50$ liter $=169.100$ liter perhari. Sedangkan perkiraan limbah yang dihasilkan gedung/kantor BPPT sebesar 3.382 orang $\times 40$ liter $=135.280$ liter/hari. Apabila diharapkan 30\% dari air limbah tersebut dapat di daur ulang maka kapasitas unit daur ulang air limbah sebesar $30 \% \times 135.280$ liter $=36.984$ liter/hari setara $41 \mathrm{~m}^{3} /$ hari.

Dari kedua pendekatan pemakaian air di atas maka dapat diketahui bahwa berdasarkan pemakaian air PAM perbulan diketahui jumlah air limbah yang dapat didaur ulang adalah 55,8 $\mathrm{m}^{3} /$ hari. Sedangkan pemakaian air berdasarkan jumlah pegawai, maka diketahui diketahui jumlah air limbah yang dapat didaur ulang adalah 41 $\mathrm{m}^{3} /$ hari. Dari hasil perhitungan di atas maka untuk penentuan minimal perencanaan kapasitas unit daur ulang akan diambil untuk nilai yang paling besar yaitu $55,8 \mathrm{~m}^{3} /$ hari. Untuk dapat mencapai target tersebut, kapasitas terpasang unit daur ulang yang digunakan harus mempunyai skenario sekitar 60 s.d. $100 \mathrm{~m}^{3}$ perhari. Dengan adanya teknologi daur ulang air limbah tersebut, maka pemakaian air akan dapat dihemat maksimal sampai $100 \mathrm{~m}^{3}$ perhari.

\section{b. Hasil Survei kondisi Unit Daur Ulang saat ini.}

Kapasitas unit daur ulang air limbah saat ini adalah sekitar $25 \mathrm{~m}^{3} /$ hari. Unit daur ulang ini menggunakan 1 buah tangki reaktor dan 2 buah tangki filter berisi media pasir silika dan karbon (Gambar 6).

Cara kerja unit daur ulang saat ini adalah air outlet limbah dipompa menggunakan dua buah pompa bekerja secara bergantian menuju filter pertama yang berisi pasir silika kemudian dialirkan ke filter kedua yang berisi karbon aktif. Setelah disaring air disimpan di bak penampung dengan kapasitas sekitar $5 \mathrm{~m}^{3}$ (Gambar 8 dan 9).

Produk air tersebut didistribusikan dengan menggunakan 2 buah pompa yang bekerja secara bergantian. Untuk meningkatkan pendistribusian air, sistem pemompaan tersebut dibantu dengan sebuah tangki air (Gambar 10). Air daur ulang ini digunakan untuk penyiraman tanaman di sekitar kantor BPPT.

Untuk mengetahui kualitas air hasil daur ulang, pelaksana survai juga telah mengambil sampel air hasil daur ulang (Gambar 11). Untuk membandingkan hasilnya, juga dilakukan pengambilan sampel air PDAM dan air sumur penduduk sekitarnya untuk dianalisakan di laboratorium. Hasil analisa sampel tersebut terlihat pada Tabel 1.

Hasil evaluasi kinerja unit daur ulang air limbah yang ada saat ini adalah:

- Hasil pengujian laboratorium diketahui bahwa nilai permanganat $\left(\mathrm{KMnO}_{4}\right)$ berada diatas baku mutu.

- Air hasil daur ulang secara fisik terlihat kurang baik (tidak jernih),

- Dari hasil perbandingan nilai analisa air antara air PAM, air sumur penduduk dan air hasil daur ulang, terlihat bahwa kualitas air hasil daur ulang mempunyai nilai yang paling rendah. Berdasarkan PP RI No. 82 Tahun 2001, maka kualitas air hasil daur ulang air limbah yang digunakan untuk siram tanaman minimal harus memenuhi baku mutu Kelas IV.

- Unit daur ulang ini secara sistem kurang memenuhi standar pengolahan air bersih karena sistem pencucian kembali filter (backwash) kurang berjalan dengan baik. Hal ini menyebabkan media filter cepat kotor dan mengakibatkan kebuntuan.

- Frekuensi penggantian media filter lebih cepat karena media filter cepat kotor dan jenuh serta pekerjaan penggantian media filter ini cukup berat karena dengan mencuci media harus mengeluarkan dan memasukkan kembali sekitar 20 karung media dengan masing-masing beratnya $20 \mathrm{~kg}$.

\subsection{Perencanaan Teknologi Daur Ulang Air Limbah}

Perencanaan teknologi daur ulang air limbah dilakukan untuk menentukan teknologi daur ulang air limbah yang paling sesuai dengan kondisi kantor BPPT. Dalam merancang maka uraian disain kriteria dan langkah perencanaan diuraikan berdasarkan hasil survei pemakaian air rata-rata bulanan di kantor BPPT dan pemakaian 
air berdasarkan jumlah pegawai yang ada dikantor BPPT. Serta evaluasi kondisi unit daur ulang air limbah yang ada saat ini.

Beberapa alternatif teknologi daur ulang air limbah antara lain dengan menggunakan :

1. Penyaringan (Filter),

2. Penyaringan ditambah Ultra filtrasi (UF), dan

3. Penyaringan, Ultra Filtrasi ditambah Reverse Osmosis (RO).

Teknologi daur ulang air limbah dengan menggunakan penyaringan dapat menghasilkan produk air bersih yang dapat digunakan untuk siram tanaman maupun untuk cuci-cuci (Gambar 12). Teknologi daur ulang air limbah dengan menggunakan penyaringan ditambah dengan unit ultra filtrasi (UF) dapat menghasilkan produk air bersih yang lebih baik dapat digunakan untuk siram-siram tanaman maupun untuk mencuci kendaraan. (Gambar 13).

Teknologi daur ulang air limbah dengan menggunakan penyaringan ditambah dengan unit ultra filtrasi (UF) kemudian ditambah dengan unit reverse osmosis (RO) akan menghasilkan produk air yang setara dengan air minum dan dapat digunakan untuk flushing toilet ataupun cooling tower serta lainya yang membutuhkan air dengan kualitas yang lebih baik dari air PAM (Gambar 14).

Proses pengolahan daur ulang air limbah dengan menggunakan filter, UF dan RO adalah sebagai berikut (8): Air limbah hasil olahan dari proses biofilter ditampung di dalam Bak Penampung Antara-1 (BPA-1). Air hasil olahan tersebut sebagian diolah lebih lanjut untuk digunakan kembali, sedangkan sisanya (over flow) dibuang ke saluran umum. Air limbah dari BPA-1 dipompa sambil diinjeksi dengan larutan kalium permanganat untuk mengoksidasi zat besi atau mangan yang ada di dalam air limbah, selanjutnya dialirkan ke filter pasir bertekanan (presssure filter). Filter pasir tersebut berfungsi untuk menyaring partikel padatan yang tersuspensi yang ada di dalam air limbah serta oksida besi atau oksida mangan yang terjadi akibat oksidasi pembubuhan kalium permanganat.

Dari filter pasir, air limbah dialirkan ke filter mangan zeolit (manganese greensand filter) yang berfungsi untuk menghilangkan zat besi atau mangan yang belum sempat teroksidasi, dan dari filter mangan zeolit, air limbah selanjutnya dilalirkan ke filter karbon aktif (activated carbon filter) yang berfungsi untuk menghilangkan bau serta polutan mikro yang masih ada di lamam air limbah. Air olahan dari filter karbon aktif dialirkan ke bak penampung antara-2 (BPA-2). Air olahan di BPA-2 selanjutnya diproses dengan menggunakan filter ultrafiltrasi dengan derajad penyaringan $0,1-0,01$ mikron. Proses penyaringan ultrafiltrasi berjalan secara otomatis yaitu 15 menit penyaringan dan 1 menit pencucian balik. Air hasil penyaringan ultrafiltrasi ditampung di bak penampung air bersih. Air hasil penyaringan ultrafiltrasi mempunyai kualitas setara dengan air bersih dan digunakan untuk keperluan siram tanaman.

Air olahan dari proses penyaringan ultrafiltrasi selanjutnya diolah lebih lanjut untuk mendapatkan air olahan dengan kualitas yang setara dengan kualitas air minum. Proses pengolahnnya menggunakan filtrasi membrane reverse osmosis yang dapat menyaring partikel sampai ukuran 0,001-0,0001 mikron. Dengan sistem filtrasi membran reverse osmosis maka seluruh mikro organisme patogen serta garamgaram yang ada di dalam air dapat dipisahkan.

Proses pengolahan dengan sistem reverse osmosis terdiri dari beberapa tahap yaitu air dari bak penampung air bersih dipompa ke filter cartridge yang dapat menyaring partikel sampai ukuran 1-5 mikron. Dari filter cartridge air dipompa ke unit membran reverse osmosis dengan menggunakan pompa tekanan tinggi. Tekakan operasi pompa berkisar antara $10-20$ Bar. Air yang keluar dari membran RO ada dua yakni pertama air olahan produk $\mathrm{RO}$ yang dilairkan ke bak penampung air PAM, sedangkan yang ke dua adalah air reject yang merupakan air yang buangan dan dialirkan ke bak penampung antara-1 (BPA-1) untuk diolah kembali. Air produk RO merupakan air dengan kualitas yang sangat baik.

\section{KESIMPULAN}

Dari hasil kegiatan diatas dapat diambil beberapa kesimpulan antara lain :

- Pemakaian air berdasarkan pemakaian air PAM setiap bulan di kantor BPPT setiap hari rata-rata berkisar 234.200 liter perhari.

- Dari hasil di atas di tentukan pemakaian air yang terbesar adalah pemakaian air berdasarkan data pemakaian dari PAM, maka diasumsikan $80 \%$ dari jumlah pemakaian air tersebut akan menjadi air limbah atau sebesar $187,36 \mathrm{~m}^{3} /$ hari.

- Dengan asumsi $30 \%$ air limbah yang akan didaur ulang, maka berdasarkan pemakaian air PAM perbulan diketahui jumlah air limbah yang dapat didaur ulang adalah $55,8 \mathrm{~m}^{3} /$ hari.

- Kapasitas unit daur ulang air limbah dapat ditingkatkan $100 \mathrm{~m}^{3} /$ hari.

- Kapasitas aman unit pengolah air limbah adalah $250 \mathrm{~m}^{3} /$ hari.

- Kondisi unit daur ulang air limbah saat ini tidak berfungsi dengan baik dan kualitas hasil air produk unit daur ulang air limbah saat ini tidak memenuhi syarat sebagai air bersih. 
- Untuk meningkatkan kinerja unit daur ulang air limbah yang ada saat ini, perlu beberapa alternatif penanganan misalnya: modifikasi dan perbaikan sistem berikut penggantian peralatan atau disain ulang (re-design).

- Salah satu alternatif perencanaan teknologi daur ulang air limbah yaitu dengan kombinasi filter, ultra filtrasi dan reverse osmosis (RO). Dengan pemilihan teknologi ini dapat menghasilkan air dengan kualitas yang sangat baik.

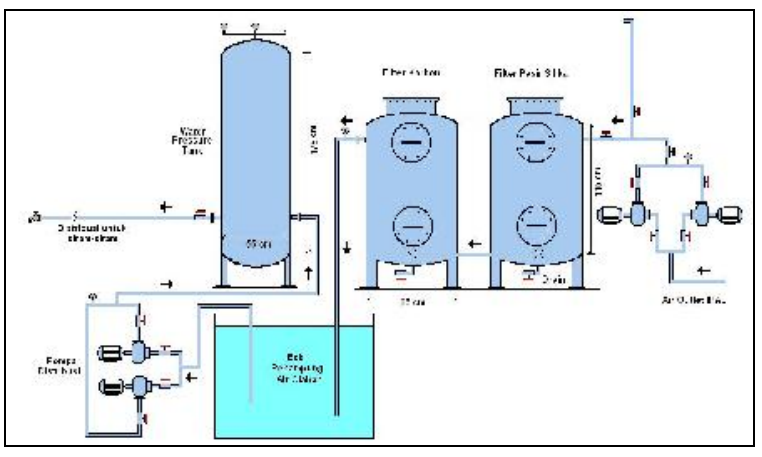

Gambar 6. Unit Daur Ulang Air Limbah Yang Ada Saat Ini

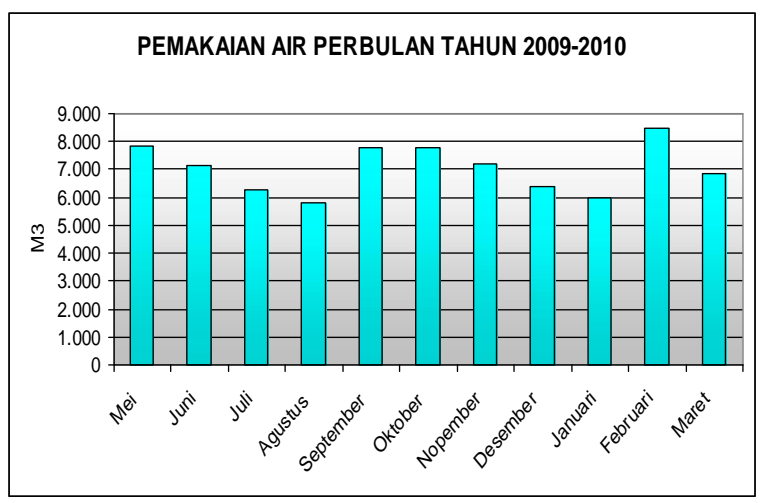

Gambar 7. Jumlah Pemakaian Air PAM Setiap Bulan Dari Mei 2009 S.D Maret 2010

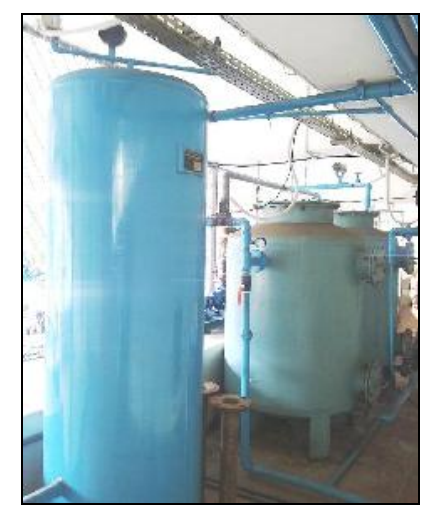

Gambar 8. Unit Daur Ulang Air Limbah BPPT Yang Ada Saat Ini

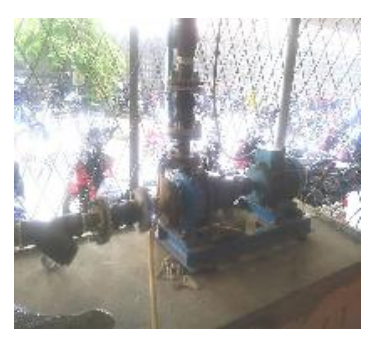

Gambar 9. Pompa Inlet Dari Air Hasil Pengolahan Limbah

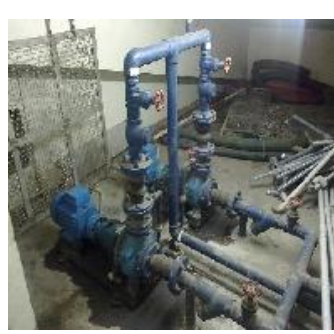

Gambar 10. Pompa Distribusi Air Hasil Olahan Daur Ulang

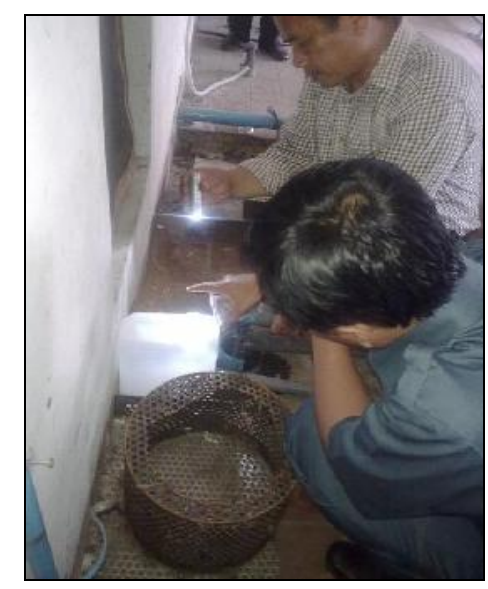

Gambar 11. Pengambilan Sampel Air Hasil Olahan Unit Daur Ulang Air Limbah untuk Dianalisa

\section{DAFTAR PUSTAKA}

1. Said, Idaman Nusa, Teknologi Pengelolaan Air Minum - Teori dan Pengalaman Praktis, Pusat Teknologi Lingkungan, BPPT, 2008.

2. Anonim, Daur Ulang Krisis Air Bersih, (http:// www.greenradio.fm/index.php?option $=$ com $c$ ontent\&view=article\&id=422: daur-ulangsolusi-krisis-air-bersih\&catid=1:latestnews\&ltemid=336).

3. Said, Nusa Idaman, Daur Ulang Air Limbah (Water Recycle) Ditinjau Dari Aspek Teknologi, Lingkungan dan Ekonomi Jurnal Air Indonesia Vol. 2 , No. 2, 2006.

4. ........,EPA, Water Recycling and Reuse: The Environmental Benefits, http://www.epa.gov/ region9/water/recycling/index.html, 2009

5. C. Aoki, M.A. Memon, WATER AND WASTEWATER REUSE: An Environmentally Sound Approach for Sustainable Urban Water Management, UNEP, www.unep.or.jp/ booklet-wastewater_Reuse.pdf, 2009.

6. Peraturan Gubernur DKI Jakarta No. 122 Tahun 2005 tentang Pengelolaan Air Limbah Domestik di Provinsi Daerah Khusus Ibukota Jakarta, 2005.

7. Biro SDMO, Rekapitulasi Data Pegawai BPPT Tahun 2010. 
8. Peraturan Menteri Dalam Negeri Nomor 1 Tahun 2007 Tentang Penataan Ruang Terbuka Hijau Kawasan Perkotaan, 2007

9. Peraturan Pemerintah Republik Indonesia Nomor 82 Tahun 2001 Tentang Pengelolaan Kualitas Air Dan Pengendalian Pencemaran Air, 2001

\section{LAMPIRAN}

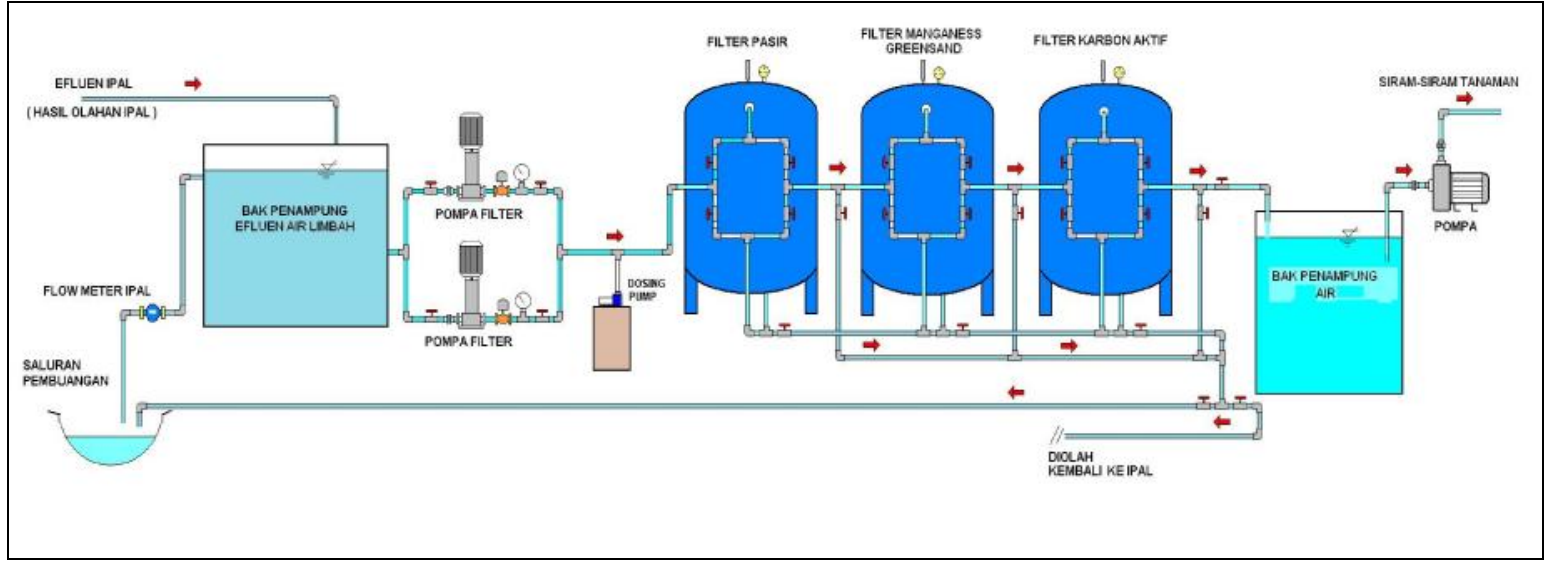

Gambar 12. Unit Daur Ulang Air Limbah Menggunakan Sistem Filter

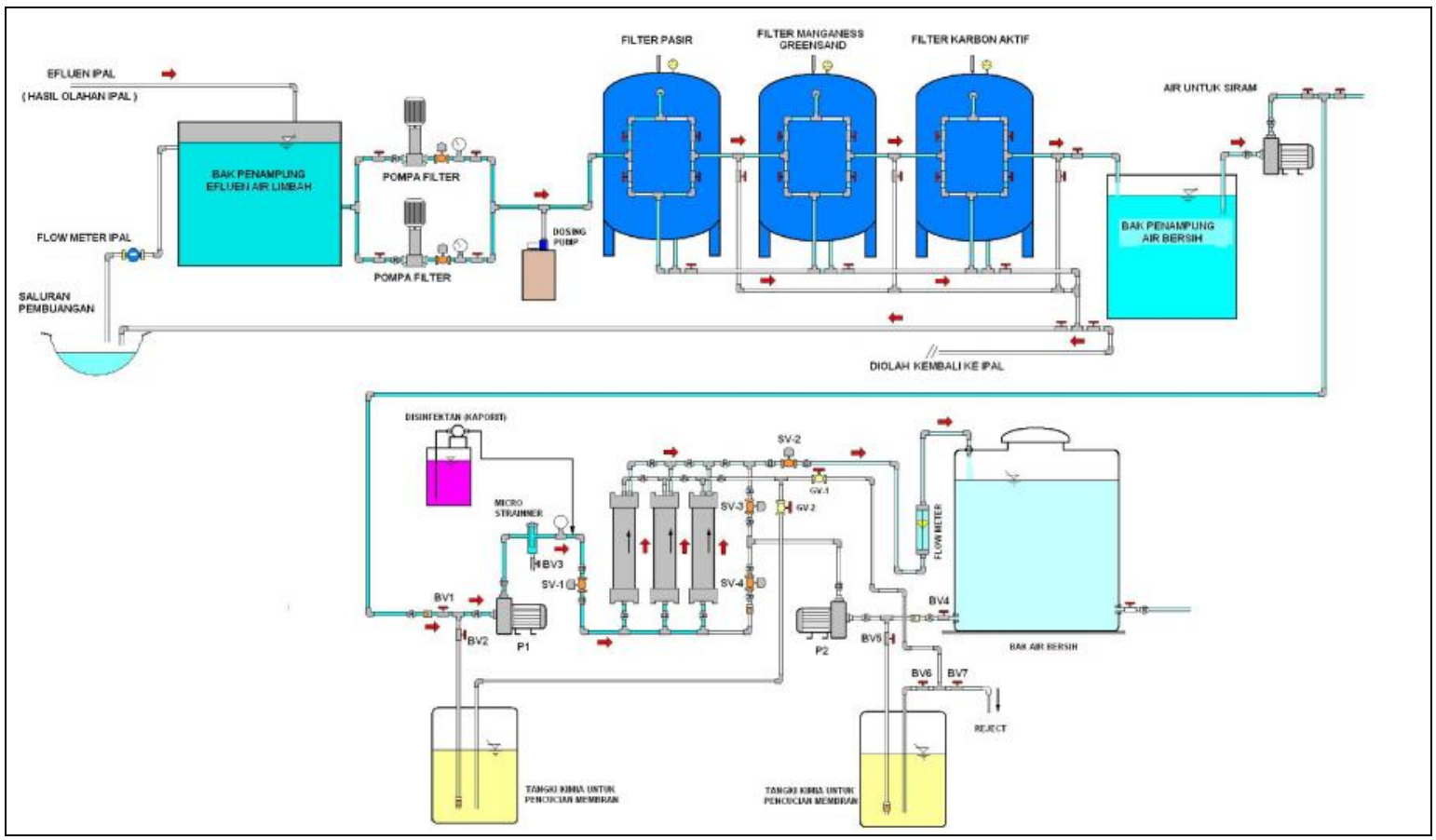

Gambar 13. Gabungan Antara Filter Dan Ultra Filtrasi 


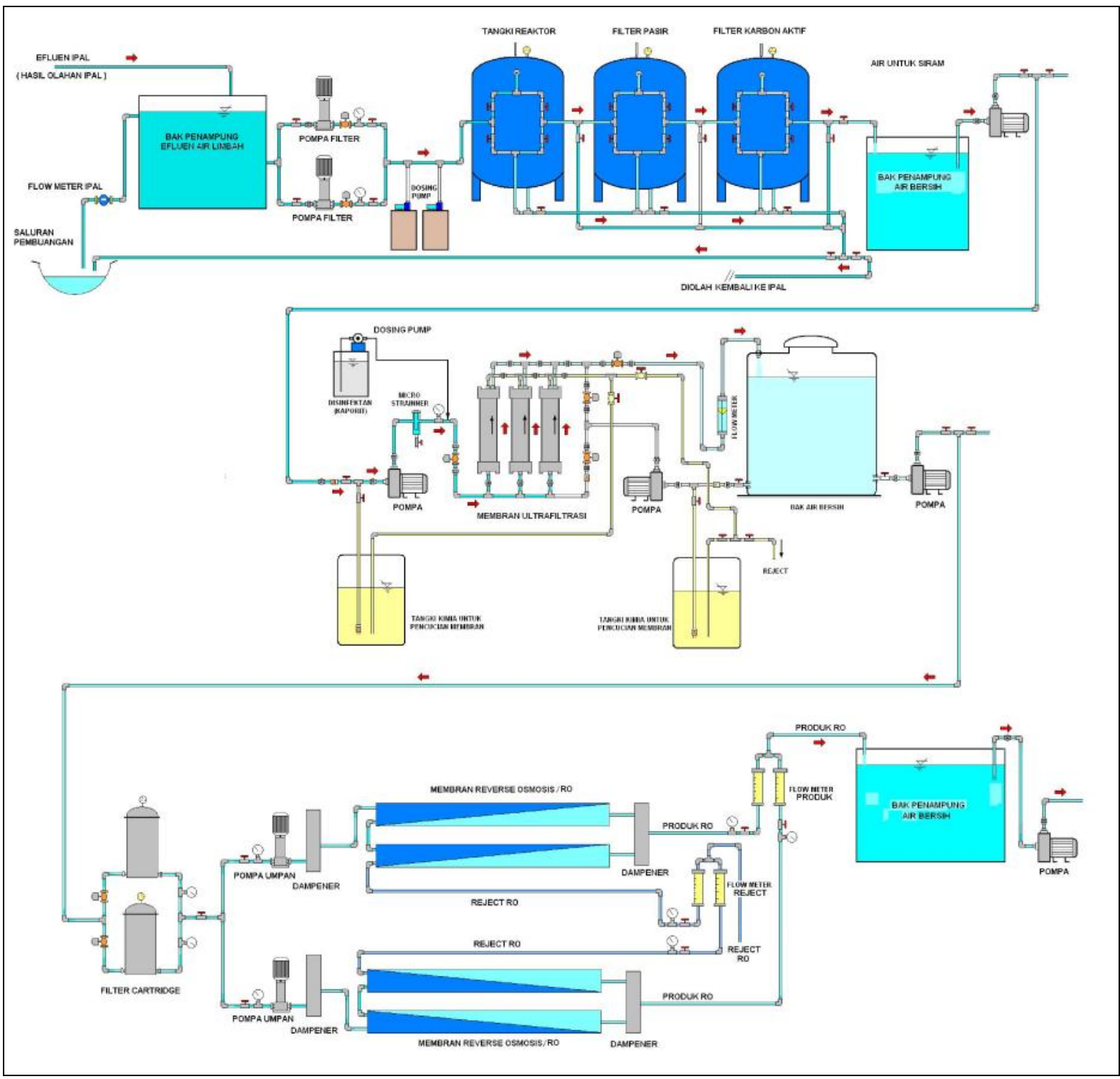

Gambar 14. Gabungan Antara Filter, Ultra Filtrasi (UF) Dan Reverse Osmosis (RO) 
Tabel 1. Sampel Air PDAM, Air Sumur Penduduk Dan Air Hasil Daur Ulang Saat Ini

\begin{tabular}{|c|c|c|c|c|c|c|}
\hline NO. & PARAMETER & SATUAN & $\begin{array}{l}\text { BAKU *) } \\
\text { MUTU }\end{array}$ & $\begin{array}{c}\text { HASIL } \\
\text { Air PDAM }\end{array}$ & $\begin{array}{c}\text { HASIL } \\
\text { Air Sumur } \\
\text { Penduduk }\end{array}$ & $\begin{array}{c}\text { HASIL } \\
\text { Air Hasil } \\
\text { Daur ulang }\end{array}$ \\
\hline A. & FISIKA & & & & & \\
\hline 1. & Bau & - & Tdk berbau & Tdk berbau & Tdk berbau & Tdk berbau \\
\hline 2. & Zat padat terlarut (TDS) & $\mathrm{Mg} / \mathrm{l}$ & 1500 & 138 & 130 & 288 \\
\hline 3. & Kekeruhan & NTU & 25 & 1 & 1 & 12 \\
\hline 4. & Rasa & - & Tdk.berasa & Tdk.berasa & Tdk.berasa & Tdk.berasa \\
\hline 5. & Suhu & ${ }^{\circ} \mathrm{C}$ & Udara $\pm 3^{\circ} \mathrm{C}$ & 26,0 & 25,9 & 26,0 \\
\hline & Warna & Pt-Co & 50 & 2 & 2 & 14 \\
\hline B & KIMIA & & & & & \\
\hline 1. & $\mathrm{PH}\left(26^{\circ} \mathrm{C}\right)$ & - & $6,5-9,0$ & 7,5 & 7,6 & 7,4 \\
\hline 2. & Air Raksa $(\mathrm{Hg})$ & $\mathrm{Mg} / \mathrm{l}$ & 0,001 & $<0,0005$ & $<0,0005$ & $<0,0005$ \\
\hline 3. & Arsen (as) & $\mathrm{Mg} / \mathrm{l}$ & 0,05 & $<0,005$ & $<0,005$ & $<0,005$ \\
\hline 4. & Besi (Fe) & $\mathrm{Mg} / \mathrm{l}$ & 1,0 & $<0,06$ & $<0,06$ & $<0,06$ \\
\hline 5. & Fluorida $(\mathrm{F})$ & $\mathrm{Mg} / \mathrm{l}$ & 1,5 & 0,30 & 0,17 & 0,42 \\
\hline 6. & Kadmium (Cd) & $\mathrm{Mg} / \mathrm{l}$ & 0,005 & $<0.003$ & $<0.003$ & $<0.003$ \\
\hline 7. & Kesadahan total $\left(\mathrm{CaCO}_{3}\right)$ & $\mathrm{Mg} / \mathrm{l}$ & 500 & 70,5 & 50,8 & 66,5 \\
\hline 8. & Khlorida (Cl) & $\mathrm{Mg} / \mathrm{l}$ & 600 & 17,6 & 18,1 & 40,1 \\
\hline 9. & Khromium VI $\left(\mathrm{Cr}^{6+}\right)$ & $\mathrm{Mg} / \mathrm{l}$ & 0,05 & $<0,01$ & $<0,01$ & $<0,01$ \\
\hline 10. & Mangan (Mn) & $\mathrm{Mg} / \mathrm{l}$ & 0,5 & 0,08 & 0,07 & 0,09 \\
\hline 11. & Nitrat (N03-N) & $\mathrm{Mg} / \mathrm{l}$ & 10 & 1,8 & 1,8 & 1,5 \\
\hline 12. & Nitrit (N02-N) & $\mathrm{Mg} / \mathrm{l}$ & 1,0 & $<0,002$ & $<0,003$ & $<0,002$ \\
\hline 13. & Selenium (Se) & $\mathrm{Mg} / \mathrm{l}$ & 0,01 & $<0,002$ & $<0,002$ & $<0,002$ \\
\hline 14. & Seng $(Z n)$ & $\mathrm{Mg} / \mathrm{l}$ & 15 & $<0,01$ & $<0,01$ & $<0,01$ \\
\hline 15. & Sianida $(\mathrm{CN})$ & $\mathrm{Mg} / \mathrm{l}$ & 0,1 & $<0,005$ & $<0,005$ & $<0,005$ \\
\hline 16. & Sulfat $\left(\mathrm{SO}_{4}\right)$ & $\mathrm{Mg} / \mathrm{l}$ & 400 & 33,2 & 41,5 & 27,4 \\
\hline 17. & Surfactan anion (MBAS) & $\mathrm{Mg} / \mathrm{l}$ & 0,5 & 0,03 & 0,03 & 0,14 \\
\hline 18. & Timbal (Pb) & $\mathrm{Mg} / \mathrm{l}$ & 0,05 & $<0,01$ & $<0,01$ & $<0,01$ \\
\hline 19. & $\begin{array}{l}\text { Nilai Permanganat } \\
\left(\mathrm{KMnO}_{4}\right)\end{array}$ & $\mathrm{Mg} / \mathrm{l}$ & 10 & 2,3 & 3,2 & 18,0 \\
\hline C. & MIKROBIOLOGI & & & & & \\
\hline 1. & Koliform & $\begin{array}{l}\text { MPN/100 } \\
\mathrm{ml}\end{array}$ & 50 & 0 & 0 & 28 \\
\hline
\end{tabular}


Lampiran II : Peraturan Gubernur Provinsi DKI Jakarta Nomor 122 tahun 2305

Tanggal 19 Oktober 2005

BESARAN POPULATION EQUIVALEN (PE) UNTUK PERANCANGAN IPAL BERDASARKAN JENIS PERUNTUKAN BANGUNAN

\begin{tabular}{|c|c|c|c|c|c|c|}
\hline No & $\begin{array}{c}\text { Peruntukan } \\
\text { Bangunan }\end{array}$ & $\begin{array}{l}\text { Pemakaian } \\
\text { Air Bersih }\end{array}$ & $\begin{array}{c}\text { Debit } \\
\text { Air Limbah }\end{array}$ & Satuan & PE & Acuan \\
\hline 1. & Rumah Mewah & 250 & 200 & Liter/penghuni/hari & 1,67 & $\begin{array}{l}\text { Perancangan dan Pemeliharaan Sistem Plambing, } \\
\text { Soufyan M. Noerbambang dan Takeo Norimura }\end{array}$ \\
\hline 2. & Rumah Biasa & 150 & 120 & Literipenghuni/hari & 1,00 & Study JICA 1990 (proyeksi 2010) \\
\hline 3. & Apartmen: & 250 & 200 & Literipenghuni/hari & 1,67 & $\begin{array}{l}\text { Perancangan dan Pemeliharaan Sistem Plambing, } \\
\text { Soufyan M. Noerbambang dan Takeo Norimura }\end{array}$ \\
\hline 4. & Rumah Susun & 100 & 80 & Liter/penghuni/hari & 0,67 & \\
\hline 5. & Asrama & 120 & 96 & Liter/penghunihari & 0,80 & \\
\hline 6. & Klinik / Puskesmas & 3 & 2,7 & Liter/pengunjung/hari & 0,02 & $\begin{array}{l}\text { Perancangan dan Pemeliharaan Sistem Plambing, } \\
\text { Soufyan M. Noerbambang dan Takeo Norimura }\end{array}$ \\
\hline \multirow[t]{3}{*}{7.} & Rumah sakit Mewah & 1000 & 800 & Liter/jumlah tempat tidur pasien/hari & 6,67 & $\begin{array}{l}\text { Perancangan dan Pemeliharaan Sistem Plambing, } \\
\text { Soufyan M. Noerbambang dan Takeo Norimura }\end{array}$ \\
\hline & Rumah Sakit Menengah & 750 & 600 & Liter/jumlah tempat tidur pasien/hari & 5,00 & $\begin{array}{l}\text { Perancangan dan Pemeliharaan Sistem Plambing, } \\
\text { Soufyan M. Noerbambang dan Takeo Norimura }\end{array}$ \\
\hline & Rumah Sakit Umum & 425 & 340 & Liter/jumlah tempat tidur pasien/hari & 2,83 & $\begin{array}{l}\text { Perancangan dan Pemeliharaan Sistem Plambing, } \\
\text { Soufyan M. Noerbambang dan Takeo Norimura }\end{array}$ \\
\hline 8. & Sekolah Casar & 40 & 32 & Liter/siswahari & 0,27 & SNI 03-7065-2005 \\
\hline 9. & SLTP & 50 & 40 & Liter/siswahari & 0,33 & SNI 03-7065-2005 \\
\hline 10. & SLTA & 80 & 64 & Liter/siswahari & 0,53 & SNI 03-7065-2005 \\
\hline 11. & Perguruan Tinggi & 80 & 64 & Liter/mahasiswa/hari & 0,53 & SNI 03-7065-2005 \\
\hline 12. & $\begin{array}{l}\text { Rumah Toko I Rumah } \\
\text { Kantor }\end{array}$ & 100 & 80 & Lter/penghuni dan pegawaihari & 0,67 & SNI 03-7065-2005 \\
\hline 13. & Gedung Kantor & 50 & 40 & Liter/pegawai/hari & 0,33 & SNI 03-7065-2005 \\
\hline 14. & $\begin{array}{l}\text { Toserba (toko serba ada, } \\
\text { mall, department store) }\end{array}$ & 5 & 4,5 & Liter $/ \mathrm{m}^{2}$ luas lantailhari & 0,04 & SNI 03-7065-2005 \\
\hline 15. & Pabrik / Industri & 50 & 40 & Liter/pegawailhari & 0,33 & SNI 03-7065-2005 \\
\hline 16. & Stasiun / Terminal & 3 & 2,7 & Liter/penumpang tiba dan pergi/hari & 0,02 & SNI 03-7065-2005 \\
\hline 17. & Bandara Udara * & 3 & 2,7 & Liter/penumpang tiba dan pergi/hari & 0,02 & $\begin{array}{l}\text { Perancangan dan Pemeliharaan Sistem Plambing, } \\
\text { Soufyan M. Noerbambang dan Takeo Norimura }\end{array}$ \\
\hline 18. & \begin{tabular}{|l|} 
Restoran \\
\end{tabular} & 15 & 13,5 & Liter/kursi/hari & 0,11 & SNI 03-7065-2005 \\
\hline 19. & Gedung Pertunjukan & 10 & 9 & Liter/kursi/hari & 0,08 & SNI 03-7065-2005 \\
\hline 20. & Gedung Bioskop & 10 & 9 & Liter/kursi/hari & 0,08 & SNI 03-7065-2005 \\
\hline 21. & Hotel Melati s/d Bintang 2 & 150 & 120 & Liter/tempat tidur/hari & 1,00 & SNI 03-7065-2005 \\
\hline 22. & Hotel Bintang 3 ke atas & 250 & 200 & Liter/tempat tidur/hari & 1,67 & SNI 03-7065-2005 \\
\hline 23. & Gedung Peribadatan & 5 & 4,5 & $\begin{array}{l}\text { Literlorang/hari (belum dengan air } \\
\text { wudhu) }\end{array}$ & 0,04 & SNI 03-7065-2005 \\
\hline 24. & Perpustakaan & 25 & 22,5 & Liter/jmlh. pengunjung/hari & 0,19 & $\begin{array}{l}\text { Perancangan dan Pemeliharaan Sistem Plambing, } \\
\text { Soufyan M. Noerbambang dan Takeo Norimura }\end{array}$ \\
\hline 25. & Bar & 30 & 24 & Liter/jmlh. pengunjung/hari & 0,20 & $\begin{array}{l}\text { Perancangan dan Pemeliharaan Sistem Plambing, } \\
\text { Soufyan M. Noerbambang dan Takeo Norimura }\end{array}$ \\
\hline 26. & Perkumpulan Sosial & 30 & 27 & Liter/jmlh. pengunjung/hari & 0,23 & $\begin{array}{l}\text { Perancangan dan Pemeliharaan Sistem Plambing, } \\
\text { Soufyan M. Noerbambang dan Takeo Norimura }\end{array}$ \\
\hline 27. & Klab Malam & 235 & 188 & Liter/jmlh. kursi/hari & 1,57 & $\begin{array}{l}\text { Perancangan dan Pemeliharaan Sistem Plambing, } \\
\text { Soufyan M. Noerbambang dan Takeo Norimura }\end{array}$ \\
\hline 28. & Gedung Pertemuan & 25 & 20 & Liter/kursi/hari & 0,17 & $\begin{array}{l}\text { Perancangan dan Pemeliharaan Sistem Plambing, } \\
\text { Soufyan M. Noerbambang dan Takeo Norimura }\end{array}$ \\
\hline 29. & Laboratorium & 150 & 120 & Liter/jmlh. staf/hari & 1,00 & $\begin{array}{l}\text { Perancangan dan Pemeliharaan Sistem Plambing, } \\
\text { Soufyan M. Noerbambang dan Takeo Norimura }\end{array}$ \\
\hline 30. & $\begin{array}{ll}\text { Pasar Tradisional I } \\
\text { Modern }\end{array}$ & 40 & 36 & Liter/kios/hari & 0,30 & $\begin{array}{l}\text { Perancangan dan Pemeliharaan Sistem Plambing, } \\
\text { Soufyan M. Noerbambang dan Takeo Norimura }\end{array}$ \\
\hline
\end{tabular}

Keterangan: * Untuk pelayanan publik

- Perhitungan menggunakan pendekatan PE hanya dipakai apabila tidak ada data aktual jumlah pemakaian air bersih per hari.

GUBERNUR PROVINSI

DAERAH KHUSUS

IBUKOTA JAKARTA 